\title{
Technè
}

La science au service de l'histoire de l'art et de la préservation des biens culturels

$43 \mid 2016$

Une Europe de la recherche en sciences du patrimoine

\section{De Eu-ARTECH à CHARISMA : l'infrastructure de recherche élargit ses compétences et son champ d'action}

\section{Isabelle Pallot-Frossard}

\section{(2) OpenEdition}

1 Journals

\section{Édition électronique}

URL : http://journals.openedition.org/techne/578

DOI : $10.4000 /$ techne. 578

ISSN : 2534-5168

Éditeur

C2RMF

\section{Édition imprimée}

Date de publication : 1 août 2016

Pagination : 23-25

ISBN : 978-2-7118-6338-9

ISSN : 1254-7867

\section{Référence électronique}

Isabelle Pallot-Frossard, «De Eu-ARTECH à CHARISMA : I'infrastructure de recherche élargit ses compétences et son champ d'action », Technè [En ligne], 43 | 2016, mis en ligne le 19 décembre 2019 consulté le 25 septembre 2020. URL : http://journals.openedition.org/techne/578 ; DOI : https:// doi.org/10.4000/techne. 578

\section{(c) $($ ) $\odot$}

La revue Technè. La science au service de l'histoire de l'art et de la préservation des biens culturels est mise à disposition selon les termes de la Licence Creative Commons Attribution - Pas d'Utilisation Commerciale - Pas de Modification 4.0 International. 


\title{
Isabelle Pallot-Frossard \\ De Eu-ARTECH à CHARISMA : l'infrastructure de recherche élargit ses compétences et son champ d'action
}

\author{
From Eu-ARTECH to CHARISMA: Expanding \\ the expertise and scope of the research \\ infrastructure
}

Résumé. De 2009 à 2013 s'est développé, sous le pilotage de Bruno Brunetti, un projet européen d'infrastructure de recherche en conservation-restauration du patrimoine, dénommé CHARISMA. L'article en dresse une brève synthèse en insistant sur les innovations apportées, telles que la mise au point d'instruments d'analyse mobiles et la mise à disposition des archives scientifiques détenues par les institutions partenaires du réseau, via l'accès transnational ARCHLAB. IL dresse enfin un rapide bilan des principales actions de valorisation des travaux.

Mots-clés. Accès transnational, archives scientifiques, instrumentation mobile, grands instruments.

\begin{abstract}
From 2009 to 2013, steered by Bruno Brunetti, a European project was developed to set up research infrastructures in the field of heritage conservation and restoration: it is called CHARISMA (Cultural Heritage Advanced Research

Infrastructures). This paper draws up a short summary of its achievements, highlighting the innovations made, namely the development of mobile analytical devices and the opportunity to consult the scientific archives of the institutions participating in the project via the ARCHLAB transnational access programme. Lastly, it briefly assesses the impact made by the research undertaken.

Keywords. Transnational access, scientific archives, mobile devices, large scale instruments.
\end{abstract}

À l'issue du projet Eu-ARTECH, en 2009, conscient de la force constituée par le réseau mis en place depuis dix ans, et par le grand intérêt scientifique de l'ouverture élargie aux chercheurs européens, le coordinateur italien Bruno Brunetti, décide de monter un troisième projet dans le cadre du $7^{\mathrm{e}}$ programme-cadre de recherche et développement : ce sera CHARISMA (Cultural Heritage Advanced Research Infrastructure ; Synergy for a Multidisciplinary Approach for Conservation-Restoration). Fondé sur les mêmes principes que le projet précédent, CHARISMA s'étend à de nouveaux pays (fig. 1), comme l'Espagne, la Hongrie, la Pologne, portant le total des pays impliqués à 11 , à de nouvelles institutions de recherche, comme le FORTH (Foundation for Research and Technology-Hellas) en Grèce, le LRMH (Laboratoire de recherche des monuments historiques) et le synchrotron SOLEIL en France, BNC (Budapest Neutron Center) et ATOMKI en Hongrie, des institutions muséales importantes comme le musée du Prado à Madrid, le British Museum à Londres et le Doerner Institut à Munich.

Ce partenariat largement étendu permet au projet d'inclure de nouveaux outils d'analyse, ajoutant aux faisceaux d'ions d'AGLAE et à l'instrumentation portable initiale de MOLAB, les analyses par activation neutronique et diffraction de neutrons, les caractérisations par rayonnement synchrotron, ainsi qu'une nouvelle palette d'instruments mobiles. Par ailleurs, l'accès transnational, jusqu'alors limité à l'analyse
In 2009, at the end of the Eu-ARTECH project, the Italian coordinator, Bruno Brunetti, was aware of the strength built up by the network set up in the last ten years and of the great scientific interest for a wider opening of infrastructure to other European researchers. He thus decides to submit a third project under the 7th Framework Programme for research and development: it will be CHARISMA (Cultural Heritage Advanced Research Infrastructure; Synergy for a Multidisciplinary Approach for Conservation-Restoration). Based on the same principles as the previous project, CHARISMA extends to new countries, such as Spain, Hungary, Poland, bringing the total number of countries involved to 11; to new research institutions, such as the FORTH (Foundation for Research and Technology - Hellas) in Greece, the LRMH (Research Laboratory on Historical Monuments) and the SOLEIL synchrotron in France, the BNC (Budapest Neutron Center) and ATOMKI in Hungary; to significant museums such as the Prado museum in Madrid, the British Museum in London and the Doerner Institute in Munich.

This greatly expanded partnership allows the project to include new analytical tools, adding to the AGLAE ion beams and to the initial MOLAB portable instruments, analysis by neutron activation and neutron diffraction, characterization by synchrotron radiation, as well as a new range of mobile instruments. Moreover, transnational access, until then limited to physicochemical analysis by ion beams or by portable tools,

Isabelle Pallot-Frossard, Conservateur général du patrimoine, directeur du Centre de recherche et de restauration des musées de France (isabelle.pallot-frossard@culture.gouv.fr). 

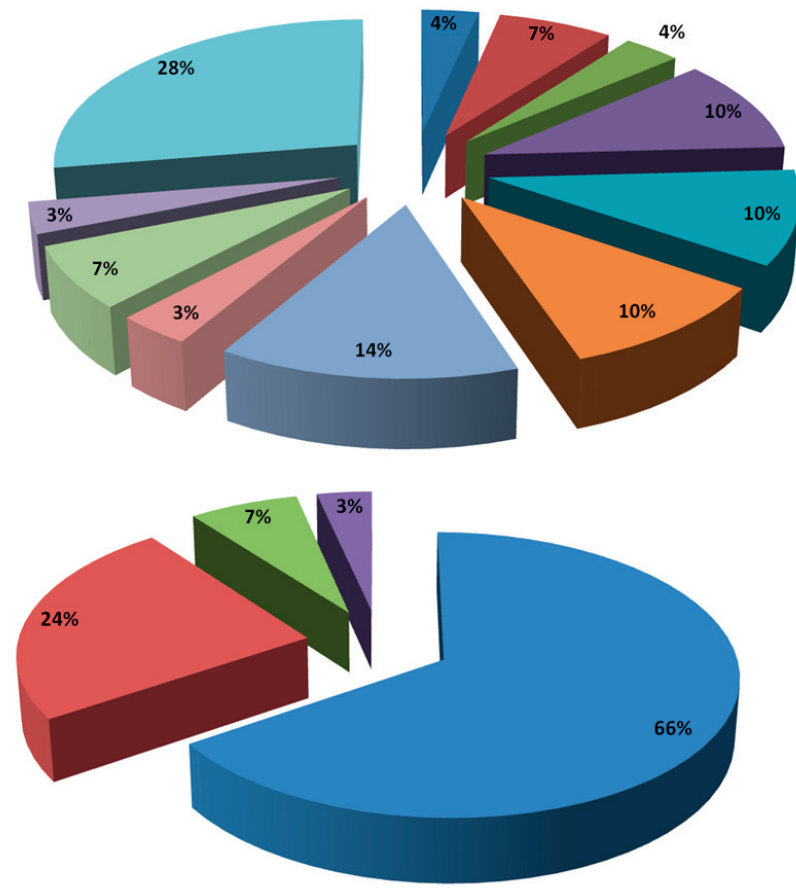

a paintings

manuscripts

mojects

architectural ornaments
Fig. 1. Diagrammes montrant la diversité des nationalités des chercheurs ayant bénéficié de l'accès MOLAB au cours du projet CHARISMA (en haut) et les sujets traités (en bas).

Diagrams showing (up) the variety of nationalities of the researchers who benefited from a MOLAB access in the framework of the CHARISMA programme and (down) the tackled issues. physico-chimique par faisceaux d'ion ou par outils portables, s'ouvre désormais à de nouvelles ressources : les grands instituts de recherche, comme les musées partenaires, mettent à disposition des chercheurs européens leurs archives scientifiques, échantillons, résultats d'analyse, imagerie scientifique, dossiers d'études ou de restaurations. Ce sera ARCHLAB, concept totalement original, qui vient démontrer que la recherche sur les matériaux du patrimoine s'inscrit dans la longue durée et qu'elle doit prendre en compte les résultats acquis dans le passé, récent ou plus lointain, et toute l'épaisseur historique de la connaissance acquise sur les œuvres ${ }^{1}$.

Comme pour l'accès à FIXLAB et MOLAB, l'accès à ARCHLAB passe par des appels à projets, qui sont soumis à un panel d'experts, juge de leur qualité scientifique et de leur faisabilité. Pendant les quatre années du projet, on aura compté 273 projets mis en œuvre, correspondant à 1390 jours d'accès pour 621 utilisateurs, provenant de plus de 20 pays différents. Pour les accès à FIXLAB, ce sont les études de type archéométrique qui dominent, sur des matériaux très divers, mais avec une majorité de métaux et de matériaux minéraux ${ }^{2}$. Pour MOLAB, ce sont les études sur la peinture qui arrivent largement en tête, avec $66 \%$ des projets, suivies de celles portant sur les manuscrits ${ }^{3}$. Pour ARCHLAB, ce sont les techniques de mise en œuvre qui sont recherchées, ainsi que les anciens traitements de conservation.

Des œuvres majeures auront été étudiées, des peintures de Jan Van Eyck, Paolo Uccello, Hans Memling, Peter Bruegel l'Ancien, Le Caravage, Vincent Van Gogh, Pablo Picasso, de même que des manuscrits enluminés, d'anciennes cartes géographiques, des pièces d'orfèvrerie, des objets en verre et is now open to a new set of resources: major research institutions, as well as partner museums, make available to European researchers their scientific archives, samples, analytical results, scientific imaging, scientific and conservation reports. This will be ARCHLAB, a totally original concept which demonstrates that research on cultural heritage materials is a long term endeavor and that it must take into account the results achieved in the past, recent or distant, and all the historical depth of knowledge gained by the study of works of $\mathrm{art}^{4}$. As for the access to FIXLAB and MOLAB, access to ARCHLAB is obtained through calls for proposals which are submitted to an expert panel who judge their scientific quality and feasibility. During the four years of the project, 273 projects have been carried out, corresponding to 1390 access days for 621 users from over 20 different countries. For FIXLAB accesses, archaeometric studies dominate, on a variety of materials but with a majority of them on metals and minerals ${ }^{5}$. For MOLAB, studies on paintings largely top the accesses with $66 \%$ of the projects, followed by those on manuscripts ${ }^{6}$. For ARCHLAB, information on execution techniques are sought after, as well as on previous conservation treatments.

Major works of art have been studied: paintings by Jan Van Eyck, Paolo Uccello, Hans Memling, Pieter Bruegel the Elder, Caravaggio, Vincent Van Gogh, Pablo Picasso, as well as illuminated manuscripts, ancient geographical maps, silverware, glass and enamels objects, mosaics, obsidian objects. It demonstrates the wide variety of cultural heritage objects that are closely examined using advanced scientific analytical methods.

In 2013, after CHARISMA, the outcomes of its Joint Research Activities will extend the range of available 
émaux, des mosaïques, des objets en obsidienne, démontrant la grande variété des œuvres patrimoniales qui sont passées au crible des méthodes d'analyse scientifique de pointe.

À l'issue de CHARISMA, en 2013, grâce à l'activité de recherches associées (Joint Research Activities), la palette d'instruments d'analyse disponible se sera élargie à l'imagerie Térahertz, qui permet la visualisation de couches sous-jacentes en peinture (fig. 2), et consolidée, avec l'imagerie hyperspectrale dans le visible et le proche Infra-rouge, combinant l'analyse et l'imagerie, ou encore la résonance magnétique nucléaire (RMN) permettant de caractériser différentes couches dans des pierres, des mortiers, des peintures... Des méthodes de diagnostic s'y sont ajoutées comme l'interférométrie laser, développée pour visualiser des défauts, fissures, décollements sur des œuvres monumentales.

Les activités de mise en réseau auront permis de mettre au point des guides de bonnes pratiques, dans le domaine des prélèvements pour analyse ou dans celui de la caractérisation des matériaux du patrimoine bâti. Une douzaine de cours et séminaires à l'intention des professionnels du patrimoine, sur le nettoyage par laser, la conservation de la pierre, les techniques spectroscopiques non-invasives ou les applications de la tomographie en cohérence optique pour la caractérisation des peintures, auront été organisés pendant la durée du projet.

Les avancées du projet se sont traduites par 103 publications, dont 76 dans des revues de rang A, ainsi que par 203 exposés oraux, conférences, posters ou séminaires. Les principaux résultats ont été présentés lors de la conférence finale les 5 et 6 mars 2014 à Florence : « Experience, Research and Innovation, a Research Infrastructure Platform for Cultural Heritage Conservation and Restoration ", qui s'est accompagnée de visites de l'Opificio delle Pietre Dure et de démonstrations scientifiques à destination des professionnels de la conservation du patrimoine. analytical instruments. They will now include Terahertz imaging, which allows the visualization of underlying layers in paintings and, in association with hyperspectral imaging in the visible and near Infrared, combines analysis and imaging, as well as nuclear magnetic resonance (NMR) to characterize different layers in stones, mortars, and paintings. Some diagnostic methods have also been added such as laser interferometry, developed to visualize defects, cracks and delaminations on monumental works of art.

Networking activities have permitted the development of best practice protocols in the field of sampling for analysis or in that of the characterization of built heritage materials. A dozen of courses and seminars for cultural heritage professionals, on laser cleaning, stone conservation, non-invasive spectroscopic techniques or applications of optical coherence tomography to the characterization of paintings have been organized during the project.

The advances from the project resulted in 103 publications, including 76 in A-ranked journals, as well as 203 oral presentations, conference lectures, posters and seminars. The main results were presented at the final conference on March 5th and 6th, 2014 in Florence: "Experience, Research and Innovation, a Research Infrastructure Platform for Cultural Heritage Conservation and Restoration", which was accompanied by visits to the Opificio delle Pietre Dure and by scientific demonstrations to cultural heritage conservation professionals.

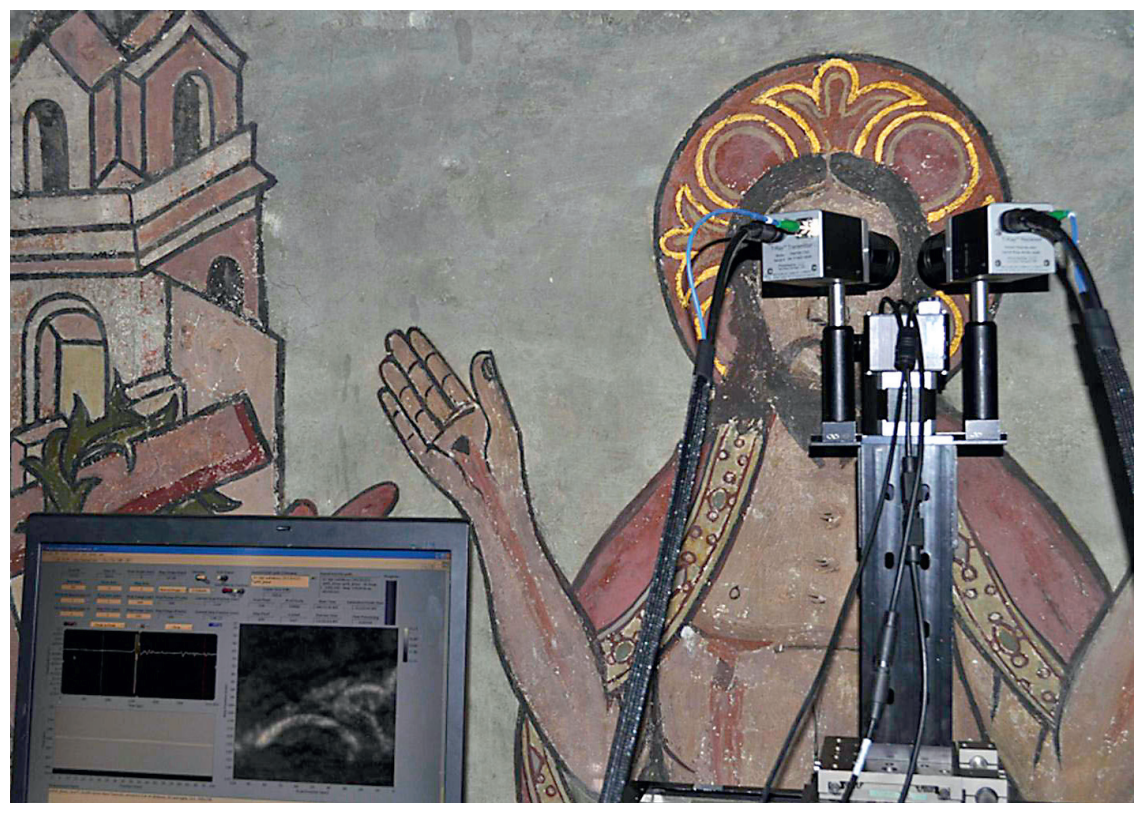

Fig. 2. Le Jugement dernier, église Saint-Thomas, Salisbury (Royaume-Uni), peinture murale, $\mathrm{XV}^{\mathrm{e}}, \mathrm{XVI}^{\mathrm{e}}$ et XIX ${ }^{\mathrm{e}}$ siècles : utilisation de la technique d'imagerie Térahertz afin de mettre en évidence les couches sous-jacentes. The Last Judgment, Saint Thomas Church, Salisbury (UK), mural painting, 15th, 16th and 19th c.: Terahertz imaging technique used to highlight the underlying layers.

(c) LRMH/D. Giovannacci.

\section{Notes}

1. Voir dans ce volume l'article de Joëlle Crétin et Clémence Raynaud.

2. Voir dans ce volume l'article de Claire Pacheco.

3. Voir dans ce volume l'article de Bruno Brunetti et Costanza Miliani.

4. See in this volume article by Joëlle Crétin and Clémence Raynaud.

5. See in this volume article by Claire Pacheco.

6. See in this volume article by Bruno Brunetti and Costanza Miliani. 